\title{
Tapaturmatutkimuksen hyödyntäminen työnopastuksessa
}

\author{
Veli-Matti Tuure ${ }^{1}$, Markku Lätti ${ }^{2}$ \\ ${ }^{1}$ TTS, PL 5, 05201 Rajamäki, veli-matti.tuure@tts.fi
}

2 TTS, PL 5, 05201 Rajamäki, markku.latti@tts.fi

\section{Tiivistelmä}

Tekninen kehitys, palkkatyövoiman ja urakoitsijoiden käyttö sekä maaseutuyritysten monimuotoisuus asettavat uusia vaatimuksia sekä työnohjaukselle että yhteistyötaidoille. Niinpä myös työn johtamista ja yrittäjätaitoja on kehitettävä työajan hallinnan rinnalla. Työnopastus on työnjohdon tehtävä, jolla pyritään varmistamaan työn tavoitteet, oikeat työmenetelmät, riittävät taidot ja työturvallisuus.

Eläinten ja koneiden kanssa työskentely ovat vaarallisimpia maataloustöitä. Käytettäessä palkkatyövoimaa maatilalla erityisesti näissä maataloustöissä työntekijöiden opastukseen on kiinnitettävä huomiota. Työnopastuksen ohjeistamiseksi ja laatimiseksi maatalousyrittäjien itsensä tekemänä koottiin tietoja oikeaoppisista ja turvallisista työskentelytavoista useista tietolähteistä. Yksi keskeisistä lähteistä olivat tapaturmaraportit.

Suomessa kaikki kuolemaan johtaneet työtapaturmat on tutkittu noin 30 vuoden ajan suomalaisen tapaturmatutkimusmallin mukaisesti. Niinpä tapaturmatutkimuksista laaditut raportit sisältävät yhdenmukaiset ja varsin yksityiskohtaiset tiedot onnettomuuksista ja niiden taustoista. Tässä tutkimuksessa analysoitiin 26 kuolemaan johtanutta maataloustapaturmaa organisatoristen, teknisten ja erityisesti inhimillisten tapaturmatekijöiden kartoittamiseksi. Tunnistetut inhimilliset tapaturmatekijät luokiteltiin kolmeentoista inhimillisten virheiden luokkaan, jotka puolestaan voidaan ryhmitellä tieto-, sääntö- ja taitoperusteisiin tilanteisiin.

Useimmissa tutkituista tapaturmista tapaturman syntymiseen vaikuttanut henkilö toimi tietopohjaisella tasolla eli tilanne oli hänelle uusi. Kuitenkin sen sijaan, että hän olisi tunnistanut toimintoanalyysin ja uuden toimintomallin tarpeellisuuden, hän oikaisi tuttuun mielleyhtymään. Muita tyypillisiä inhimillisiä virhetyyppejä olivat normaalista poikkeavan työnkulun huomaamatta jääminen sekä päätöksen tekeminen vajavaisen toimintoanalyysin perusteella poikkeavaksi tunnistetussa uudessa tilanteessa.

Tapaturmatutkimusraportit tuovat esiin tapaturman syntymisen kannalta kriittisiä tekijöitä, jotka ovat estäneet normaalin työsuorituksen - tai jotka toisin toteutettuina tai organisoituina olisivat johtaneet normaaliin, turvalliseen työsuoritukseen. Niinpä raporteissa on arvokasta tietoa turvallisen työskentelyn edellytyksistä. Tätä tietoa on syytä hyödyntää työntekijöiden työnopastuksessa.

Avainsanat: Työnopastus, tapaturmatutkimus, tapaturmatekijät, inhimilliset virheet 


\section{Johdanto}

Tekninen kehitys, töiden ulkoistaminen (palkkatyövoiman ja urakoitsijoiden käyttäminen) ja maaseutuyritysten monimuotoisuus asettavat uusia vaatimuksia sekä työnohjaukselle että yhteistyötaidoille. Niinpä myös työn johtamista ja yrittäjätaitoja on kehitettävä työajan hallinnan rinnalla. Työnopastus on työnjohdon tehtävä, jolla pyritään varmistamaan työn tavoitteet, oikeat työmenetelmät, riittävät taidot ja työturvallisuus.

Työopastus sisältää tiedot kaikista tarpeellisista työn tekemiseen liittyvistä asioista - sen avulla luodaan työntekijälle työn ja tehtävän orientaatioperusta. Työnopastusta tarvitaan, kun työpaikalle saapuu uusi työntekijä, mutta myös silloin, kun

- tehtävä on työntekijälle uusi

- tehtävä on muuttunut tai vaihtelee

- uusia koneita, laitteita, työvälineitä tai materiaaleja otetaan käyttöön

- tehtävä toistuu harvoin

- tilanne on normaalista poikkeava

- turvallisuusohjeita rikotaan tai sattuu työtapaturma

- $\quad$ annetuissa ohjeissa havaitaan puutteita

- tuotannossa tai tuotteissa havaitaan laatuongelmia.

Työnopastus on työpaikan laadunparannusväline. Riskien hallinta on osa toiminnan laadunvarmistusta. Yksilötasolla työnopastus ohjaa laatuajatteluun (kuva 1). Niinpä työnopastuksen kohteena on oltava työntekijän mentaalinen malli työstä.

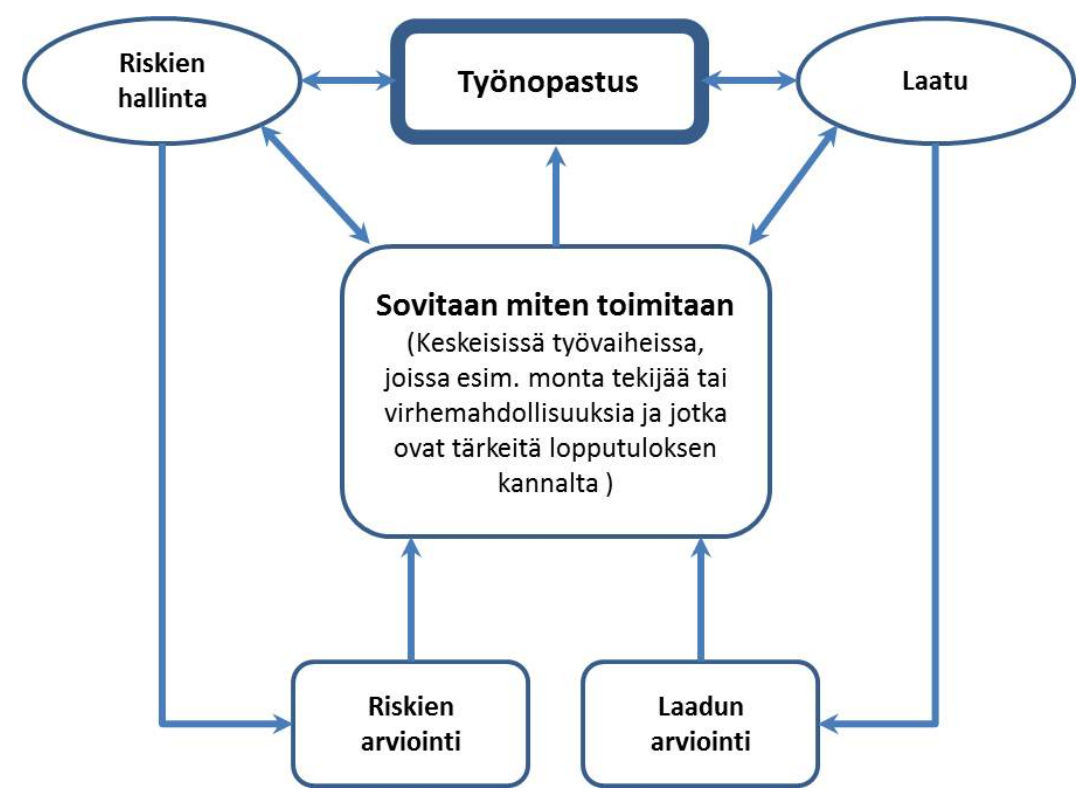

Kuva 1. Työnopastus on työpaikan laadunparannustyökalu (Työturvallisuuskeskus 2009).

Työskentely eläinten ja koneiden kanssa ovat vaarallisimpia maataloustöitä. Työtapaturmien määrä miljoonaa työtuntia kohti (tapaturmataajuus) on erityisen suuri huolto- ja korjaustöissä (Karttunen ym. 2006). Koneisiin ja laitteisiin liittyvät työtapaturmat ovat yleisimpiä kasvintuotantotöissä (noin 43 \% kaikista kasvintuotantotöiden työtapaturmista vuonna 2008) ja muissa maataloustöissä (Tike 2009). Kotieläintöissä sattuneet työtapaturmat kattoivat puolestaan yli 42 \% kaikista Suomessa sattuneista korvatuista maatalouden työtapaturmista vuonna 2009 (Mela 2010). Samana vuonna lähes 55 \% uusista työperäisistä sairauksista liittyi kotieläintuotantoon. Niinpä on ilmeistä, että käytettäessä palkkatyövoimaa tilan töissä erityisesti kotieläin- ja konetöiden työnopastukseen on kiinnitettävä huomiota.

Tämän käynnissä olevan tutkimuksen tavoitteena on tuottaa maatalousyrittäjän käyttöön ohjeet tilakohtaisten työnopastuskorttien koostamiseen erityisesti kotieläin- ja konetöihin. Tutkimus on osa 
laajempaa "Työvoiman ja työmäärän hallinta jaksamisen ja hyvinvoinnin turvaajina” -tutkimusta, jonka rahoittaa maa- ja metsätalousministeriö ja jota koordinoi Maa- ja elintarviketalouden tutkimuslaitos (MTT). Tämä esitys kohdentuu tapaturmaraporttien hyödyntämiseen työnopastuksen ohjeiston laatimisessa. Niinpä näkökulmana työnopastukseen on työturvallisuus.

\section{Aineisto ja menetelmät}

Työnopastusohjeiston tuottamiseksi maatalousyrittäjille, jotta he voisivat suunnitella ja valmistella käyttökelpoiset tilakohtaiset työnopastusohjeet, tietoa kerättiin useista tietolähteistä. Tällaisia tietolähteitä olivat mm. maataloustöiden hyvät käytännöt, prosessikuvaukset, oppimismallit ja maataloustöiden tehtäväohjeet. Lisäksi tapaturmatutkimusraportit kuuluivat analysoitaviin tietolähteisiin. Koska työtapaturmien tutkimusraportit kuvaavat työprosessien epätyypilliset etenemiset, niiden avulla pystytään tunnistamaan työympäristöissä esiintyviä tapaturmatekijöitä. Lisäksi raportit nostavat tarkasteluun inhimillisen toiminnan näissä epätyypillisissä työtilanteissa ja siten, toiminnan kuvauksen kautta, auttavat estämään samanlaisten onnettomuuksien tapahtumisen tulevaisuudessa. Verrattaessa tapaturmakuvauksia maataloustöiden hyvien käytäntöjen kuvauksiin tapaturmaraportit käsittelevät enemmän työntekijän mentaalista mallia, kun taas hyvät käytännöt keskittyvät teknisen ratkaisun, tavoitteiden ja - kuitenkin varsin harvoin - työprosessin kuvaamiseen.

Suomessa työtapaturmat on analysoitu ja kuvattu lähes 30 vuoden ajan ns. suomalaisen tapaturmatutkimusmallin mukaisesti. Niinpä tapaturmien tutkimusraportit sisältävät yhdenmukaista ja varsin yksityiskohtaista tietoa työtapaturmista ja niiden taustoista. Suomessa Tapaturmavakuutuslaitosten liitto kerää ja ylläpitää työtapaturmatilastoja ja tapaturmatutkimusraporteista koostuvaa TOTTItietokantaa. Tässä tutkimuksessa analysoitiin 26 kuolemaan johtanutta maatalouden työtapaturmaa, jotka sattuivat kone- ja kotieläintöissä (TOTTI-tietokanta 1985-2008).

Tapaturmatutkimus perustuu tutkimusmalliin, jossa tapaturmatekijät ja ihmisen toiminta ennen tapaturman sattumista kuvataan erityisen kuvaustekniikan avulla (kuva 2). Malli paljastaa tapaturman taustalla olevat kausaaliset (syy-seuraussuhteiset) tekijät. Tapaturmatutkimusprosessin tavoitteena on tunnistaa kuolemaan johtaneiden työtapaturmien tapaturmatekijät sekä ideoida ja koota keinoja vastaavien tapaturmien estämiseksi. Kuolemaan johtaneiden työtapaturmien tutkimusten tuloksia käytetään työturvallisuuden parantamiseen - työtapaturmien estämisen suunnitteluun.

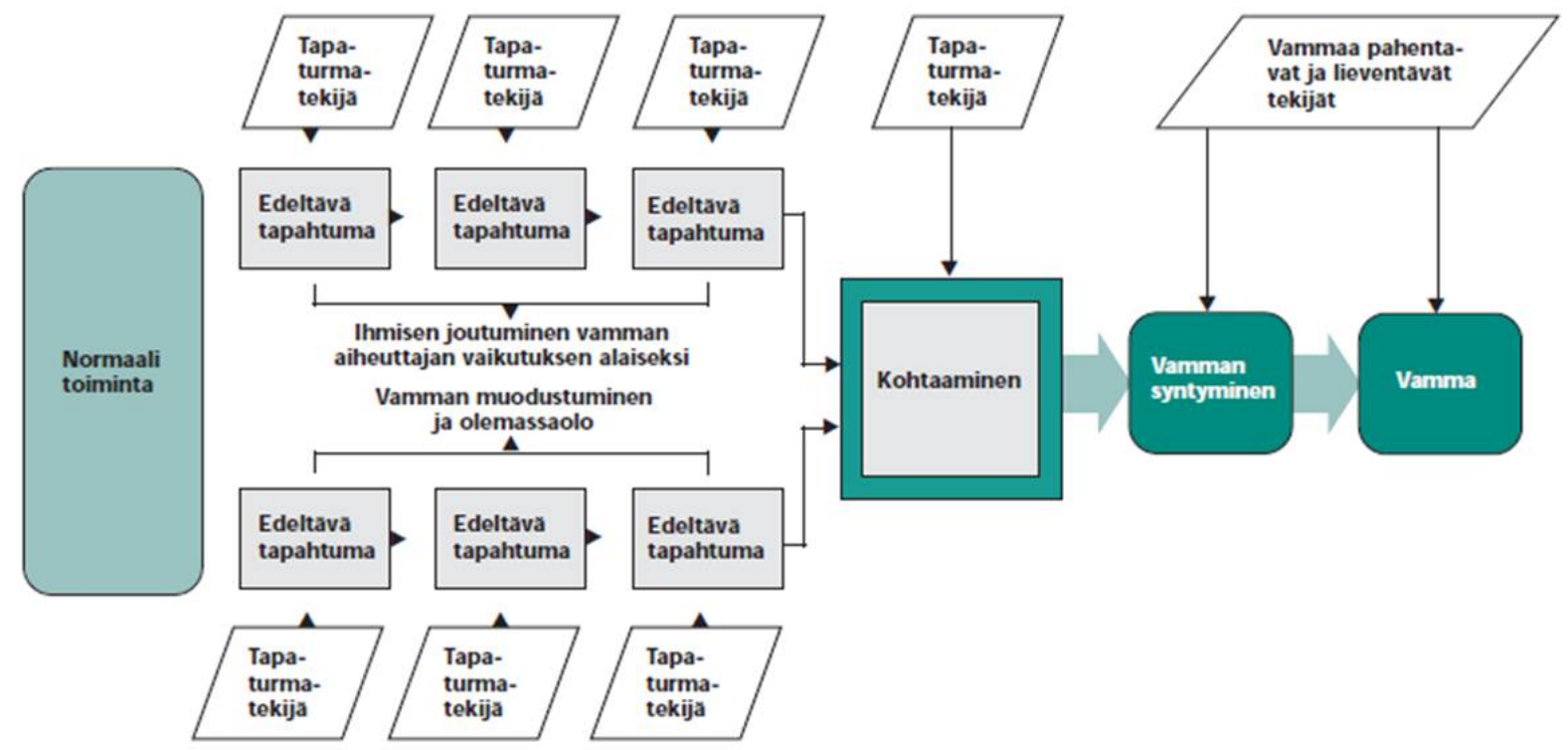

Kuva 2. Tapaturmaa edeltävien tapahtumien kulun kuvaaminen suomalaisen tapaturmatutkimusmallin mukaan.

Tapaturmatutkimusraportit nostavat esille kriittiset tekijät, jotka voivat estää normaalin työnkulun tai toisin toteutettuina tai organisoituina - mahdollistaa työn turvallisen etenemisen. Raportit sisältävät siis arvokasta tietoa turvallisen työn tekemisen ehdoista. Tätä tietoa kannattaa käyttää opastettaessa uusia työntekijöitä. Tapaturmatutkimusraportit sisältävät kuvaukset 1.) tapahtumien kulusta nor- 
maalitoiminnasta tapaturman sattumishetkeen, 2.) tapaturmatekijöistä ja 3.) toimenpiteistä, joilla samankaltaisten tapaturmien tapahtuminen voitaisiin estää.

Tutkimusraportteihin kirjattujen kuvausten perusteella tapaturmatekijät jaoteltiin ensivaiheessa organisatorisiin, teknisiin ja inhimillisiin tapaturmatekijöihin. Tunnistetut inhimilliset tapaturmatekijät luokiteltiin edelleen kolmeentoista inhimillisten virheiden luokkaan (Rasmussen 1982, ref. Sanders \& McCormick 1993; kuva 3), jotka puolestaan voidaan ryhmitellä tieto-, sääntö- ja taitoperusteisiin tilanteisiin. Virheluokat kuvaavat erilaisia tilanteita, joissa tapaturman syntymiseen vaikuttanut henkilö, usein tapaturman uhri, toimi tapaturman sattumishetkellä. Tietopohjaiseen toimintaan liittyvät virhetyypit ovat entuudestaan tuntemattomassa, uudessa päätöksentekoa edellyttävässä tilanteessa esiintyviä virhetyyppejä. Vastaavasti sääntöpohjaiseen toimintaan liittyvät virhetyypit esiintyvät tutuissa tilanteissa, joissa toimitaan ulkopuolisen informaation ohjaamana opitun toimintamallin mukaan, ja taitopohjaiseen toimintaan liittyvät virhetyypit jo pitkälle automatisoituneissa rutiinisuorituksissa.

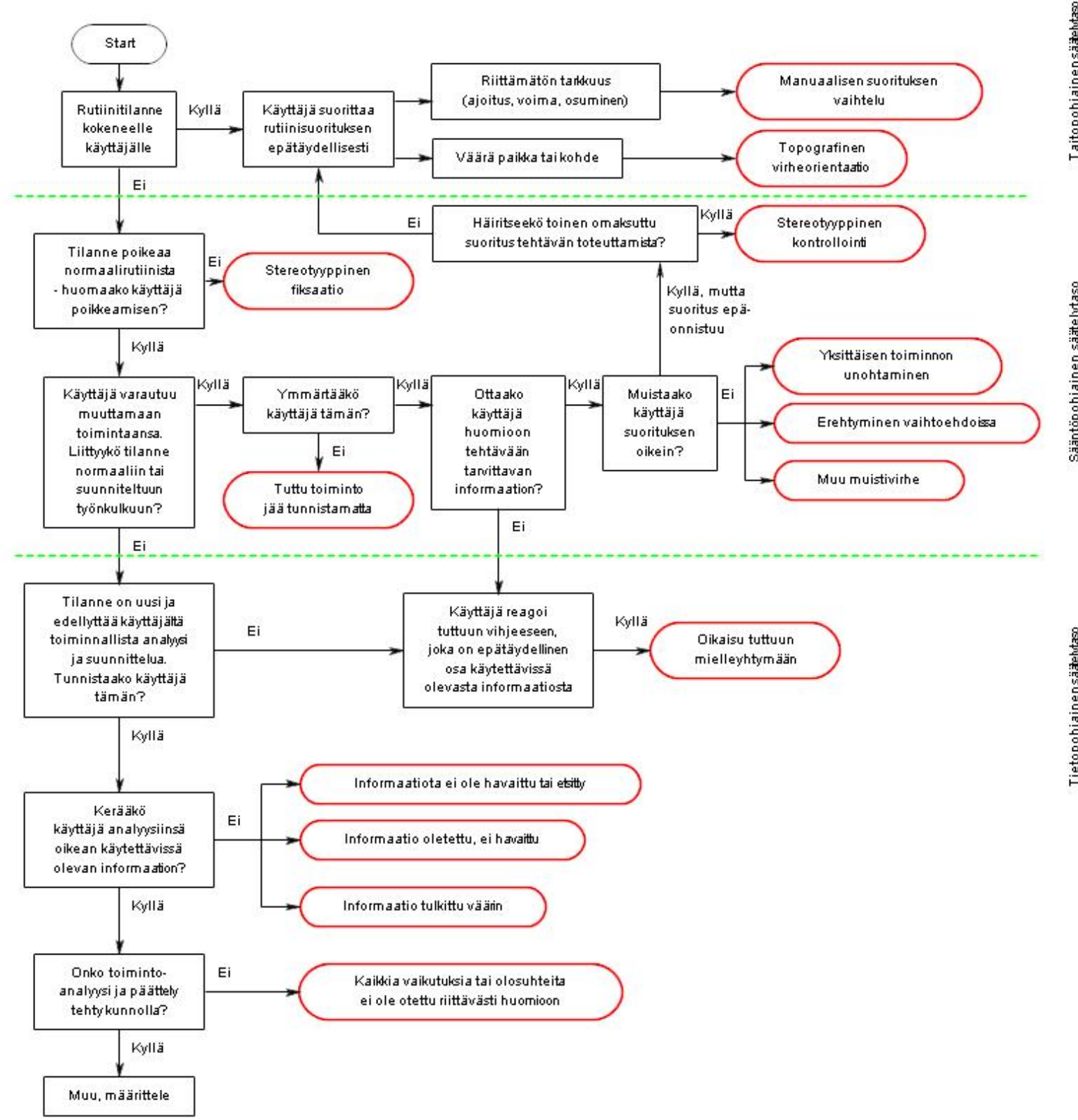

Kuva 3. Päätöksentekopuu inhimillisten virhetyyppien luokittelemiseksi (Rasmussen 1982). 


\section{Tulokset ja tulosten tarkastelu}

Tutkituista tapaturmatapauksista 21:ssä (81 \%) tunnistettiin organisatorisia tapaturmatekijöitä. Näistä yleisimmin esiintyneitä olivat riittämätön työnopastus, vähäinen ohjaus/seuranta sekä koneiden korjausten laiminlyönnit. Lähes kaikista tapauksista löytyi myös teknisiä ja fysikaalisia tapaturmatekijöitä; 24:ssä tapauksessa (92 \%) koneiden ja laitteiden virhetoiminnot, epätarkoituksenmukaiset välineet tai välineiden rikkoutuminen tunnistettiin tapaturmatekijäksi.

Inhimillisiä tapaturmatekijöitä tunnistettiin 26:ssa tapauksessa tutkituista tapaturmista. Läpikäytyjen tapaturmakuvausten perusteella useissa tapauksissa toimija oli tehnyt useita virheitä tapaturmaan johtaneen tapahtumien kulun aikana. Useimmissa tutkituista inhimillisten virheiden tapauksissa (60 \%) toimija työskenteli tietopohjaisella toiminnan säätelyn tasolla. Yleisimmässä virhetyypissä sen sijaan, että toimija olisi tunnistanut toimintoanalyysin ja uuden toimintomallin tarpeellisuuden, hän oikaisi tuttuun mielleyhtymään. Muita tyypillisiä inhimillisiä virhetyyppejä olivat normaalista poikkeavan työnkulun huomaamatta jääminen (sääntöpohjainen toiminnan säätelytaso) sekä päätöksen tekeminen vajavaisen toimintoanalyysin perusteella poikkeavaksi tunnistetussa uudessa tilanteessa (tietopohjainen toiminnan säätelytaso).

\section{Johtopäätökset}

Työnopastuksella on keskeinen rooli työtapaturmien vähentämisessä maatiloilla. Jotta maatilalla olisi edellytykset toimia työnopastuksessa tehokkaasti, maataloustyössä esiintyvät tilakohtaiset riskitekijät on välttämättä tunnistettava ja mahdollisuuksien mukaan poistettava, työntekijät ja heidän taitonsa on tunnettava sekä työnopastettavalle on annettava ohjeet oikeaoppisista ja turvallisista toimintatavoista.

Erityistä huomiota tulisi kiinnittää siihen, että opastettavat tunnistavat epänormaalin työnkulun. Pääpaino on oltava opastettavan mentaalisen mallin kehittämisessä. Opastettavalle on annettava toimintaohjeet kaikkiin mahdollisiin tilanteisiin - normaalista poikkeavassa työnkulussa ohjeena voi olla myös työn välitön keskeyttäminen ja kokeneemman henkilön paikalle kutsuminen. On myös tärkeää edistää työkulttuuria, jossa havaitut viat tai puutteet työympäristössä, tekniikassa, toimintatavoissa tai muissa työjärjestelmän osissa kerätään ja riskitekijät poistetaan systemaattisesti ja tehokkaasti. Nykyisin valtaosa työtapaturmista syntyy usean tekijän yhteisvaikutuksesta.

\section{Kirjallisuus}

Karttunen, J., Suutarinen, J., Leppälä, J., Louhelainen, K. \& Tuure, V-M. 2006. Suhteellisesti vaarallisimmat maataloustyöt - töiden organisoinnilla turvallisuutta ja tehokkuutta maitotiloille. Summary: Relative accident risk in farm work. Työtehoseuran julkaisuja 397: 1-75.

Mela. 2010. Maatalousyrittäjien eläkelaitoksen tilastot. Saatavissa: URL:// www.mela.fi > Tilastot > Aikasarjat > MATA-vahingot

Rasmussen, J. 1982. A taxonomy for describing human malfunction in industrial installations. Journal of Occupational Accidents 4: 311-333.

Sanders, M.S. \& McCormick, E.J. 1993, Human factors in engineering and design. McGraw-Hill Inc., Psychology Series. 7. painos. $790 \mathrm{~s}$.

Singer, R.N. 1980. Motor Learning and Human Performance - An Application to Motor Skills and Movement Behaviors. 3. painos. MacMillan Publishing co., Inc. New York.

Tapaturmavakuutuslaitosten liitto, Työturvallisuuskeskus, Työterveyslaitos \& Turvatekniikan keskus. 2001. Työkirja tapaturmien ja vaaratilanteiden tutkimiseen. $40 \mathrm{~s}$.

Tike. 2009. Maatilatilastollinen vuosikirja 2009. Maa- ja metsätalousministeriön tietopalvelukeskus. Edita Oy, Helsinki. $268 \mathrm{~s}$.

Työturvallisuuskeskus. 2009. Työnopastus ja riskien hallinta. Edita Oyj, 5. painos. 20 s. 